\title{
NITROGEN FERTILIZER SPLIT-APPLICATION FOR CORN IN NO-TILL SUCCESSION TO BLACK OATS
}

\author{
Carlos Alberto Ceretta ${ }^{17 *}$; Claudir José Basso2; Jeferson Diekow ${ }^{3}$; Celso Aita ${ }^{4}$; Paulo Sérgio \\ Pavinato $^{5}$; Frederico Costa Beber Vieira ${ }^{5}$; Edson Rodrigo Oliveira Vendrusculo ${ }^{6}$ \\ ${ }_{2}^{1}$ Depto. de Solos - CCR/UFSM - CEP: 97105-900 - Santa Maria, RS. \\ ${ }^{2}$ Pós-Graduando em Agronomia - CCR/UFSM. \\ ${ }^{3}$ Pós-Graduando em Ciência do Solo - UFRGS - CEP: 90001-970 - Porto Alegre, RS. \\ ${ }_{5}^{4}$ Depto. de Solos - UFSM - CEP: $97105-900$ - Santa Maria, RS. \\ ${ }^{5}$ Graduandos em Agronomia - UFSM. \\ ${ }_{7}^{6}$ Multi Agropecuária - Estrada Tupanciretã/Santiago, Km 01 - CEP: 93212-450 - Tupanciretã, RS. \\ ${ }^{7} \mathrm{CNPq}$ Fellow. \\ ${ }^{*}$ Corresponding author <ceretta@ccr.ufsm.br>
}

\begin{abstract}
The studies of fertilization splitting are necessary specially for the grass succession black oatcorn where $\mathrm{N}$ immobilization is very common. Four experiments were carried out in commercial farms under no-tillage, in four counties - Itaara, Santo Ângelo, Júlio de Castilhos and Tupanciretã, all of Rio Grande do Sul, Brazil, with the objective of evaluating the splitting of $\mathrm{N}$ application in a corn/black oat crop rotation, during the 97/98 and 98/99 cropping seasons. The $\mathrm{N}$ was applied at three times - pre-planted, starter and sidedressed. The pre-planted applied $\mathrm{N}$ for corn, corresponding to total or partial rates that would be sidedressed presented similar results in relation to the sidedress application, however, years of above average rainfall presented $\mathrm{N}$ deficiency for corn, reducing yield, which indicates that $\mathrm{N}$ application as starter or sidedress is recommended. Key words: cultural successions, mineral nitrogen, fertilization
\end{abstract}

\section{PARCELAMENTO DA ADUBAÇÃO NITROGENADA PARA O MILHO CULTIVADO EM SUCESSÃO À AVEIA PRETA EM PLANTIO DIRETO}

\begin{abstract}
RESUMO: Na sucessão de gramíneas aveia preta/milho pode haver imobilização do nitrogênio, especialmente no início do ciclo do milho, requerendo estudos de fracionamento da adubação. Com o objetivo de avaliar formas de parcelamento da adubação nitrogenada para o milho em sucessão à aveia preta, foram conduzidos quatro experimentos em áreas de lavouras sob plantio direto nos municípios de Itaara, Santo Ângelo, Júlio de Castilhos e Tupanciretã no Rio Grande do Sul, durante os anos agrícolas 1996/97 a 1998/99. As aplicações de $\mathrm{N}$ para o milho foram realizadas em três épocas: a) pré-semeadura (após o manejo da aveia preta), b) semeadura e c) cobertura. Os resultados mostraram que a aplicação em pré-semeadura do milho de parte ou todo o nitrogênio que seria aplicado em cobertura não conferiu produtividade de grãos diferente da aplicação na semeadura e cobertura mas a ocorrência de precipitações pluviométricas acima da normal pode causar diminuição na produtividade de grãos. Por isso, a aplicação de nitrogênio na semeadura e em cobertura no milho é preferencial.

Palavras-chave: sucessão de culturas, nitrogênio mineral, adubação
\end{abstract}

\section{INTRODUCTION}

The no-till system represents an important agronomic advance in order to control soil erosion. However, as each year the area managed in the no-till system increases, the thought that only crop rotations, capable of providing high dry matter production, are capable of keeping the system sustained is also consolidated. Thus, soil compaction and erosion, which are the major no-till system challenges, can be better controlled under this system.

In southern Brazil, black oat is one of the main cultivated species in winter for animal feeding, grain production and cover crops. The preference for black oats comes from its high potential for dry matter production with a high carbon/nitrogen $(\mathrm{C} / \mathrm{N})$ ratio, which allows a slow decomposition of crop residues, and that is desirable for soil protection. On the other hand, the $\mathrm{C} / \mathrm{N}$ high ratio of black oat dry matter can compromise the needed quantity of $\mathrm{N}$ for grasses as corn, cultivated in succession.

Nitrogen fertilization recommended for corn cultivated in no-till and in succession to grasses, is the application of 20 to $30 \mathrm{~kg} \mathrm{ha}^{-1}$ of $\mathrm{N}$ at sowing and the remaining as side dressing, 30 to 40 days after emergence, or when the plants are 40 to $60 \mathrm{~cm}$ tall (Comissão de Fertilidade do Solo, 1995). For the no-till system an addition of 20 to $30 \%$ of the $\mathrm{N}$ applied at sowing is recommended (Bayer, 1993) in order to minimize $\mathrm{N}$ immobilization by soil micro-organisms, which, according to Salet et al. (1997), is the main reason for the lower $\mathrm{N}$ availability to the plants in the no-till system, in comparison to the traditional soil preparation system. In spite of the low $\mathrm{N}$ demand by the corn plant at the early development stages, Ritchie et al. (1993) state that at these stages, a high $\mathrm{N}$ concentration at the root zone is desirable, since large $\mathrm{N}$ absorption promotes 
good initial growing of the plant and increases the grain productivity potential. Approximately in the second week after emergence, the beginning of floral differentiation occurs, and the number of ovules of the ear is defined (Fancelli \& Dourado Neto, 1996). This concern is highlighted by Yamada (1996), who indicated as the most important factor to detain better corn responses to nitrogen, the time when the nitrogen fertilizer is applied, since plants that received between 30 and $50 \mathrm{~kg} \mathrm{ha}^{-1}$ of $\mathrm{N}$ at sowing, presented better initial development and higher productivity than the traditionally fertilized plants, receiving 15 and $20 \mathrm{~kg} \mathrm{ha}^{-1}$ of $\mathrm{N}$.

A $\mathrm{N}$ availability increase at the beginning of the corn development cycle, can be obtained with the application, in advance, of part or all $\mathrm{N}$ that would be applied as side dressing, as observed by Sá (1996), and Basso \& Ceretta (2000). This confers flexibility to the $N$ application period and a more rational use of machinery and labor in the field, since much of the corn cultivated in southern Brazil is sown in September and October, coinciding with the operations of $\mathrm{N}$ application to corn as side dressing and the sowing of soybeans (Ceretta, 1997). However, since nitrate is the predominant form of soil mineral $\mathrm{N}$ and has high mobility, which promotes leaching, there is a possibility of jeopardizing $\mathrm{N}$ application efficiency when fertilizer is applied pre-sowing, specially when climate is characterized by intense and frequent rainfall (Ceretta, 1998).

This work was carried out in order to evaluate $\mathrm{N}$ fertilization splitting for corn, cultivated in succession to black oats under no-till, and also its influence on mineral $\mathrm{N}$ availability of the soil and on agronomic parameters as height, dry matter and corn grain productivity.

\section{MATERIAL AND METHODS}

Four experiments were carried out in no-till agricultural areas of commercial producers of the State of Rio Grande do Sul, Brazil: located between geographic coordinates $53^{\circ}$ and $54^{\circ}$ West, and $28^{\circ}$ and $29^{\circ} 30^{\prime}$ South: 1) Itaara (Tipic Paleudult soil), cropping season 1996/97, on an area under no-tillage for 8 years; 2) Santo Ângelo (Heavy clay Rhodic Hapludox soil), cropping season 1997/98, 10 years under no-tillage; 3) Júlio de Castilhos (Tipic Paleudult soil), cropping season 1998/
99, 4 years under no-tillage; 4) Tupanciretã (Tipic Paleudult soil), cropping season 1998/99, 4 years under no-tillage. Soil characteristics of the experimental areas are presented in Table 1.

Productivity of black oats that were cultivated before corn over the entire area on which the experiments were carried out, was evaluated after the grain harvest at Itaara and Júlio de Castilhos, and after cattle removal in Santo Ângelo and Tupanciretã, with yields of 3.53 , $3.00,0.33$ and $2.14 \mathrm{Mg} \mathrm{ha}^{-1}$, respectively. Black oat eradication in all the areas was made with the herbicide glyphosate, at a rate of $3 \mathrm{~kg}$ a.i. ha-1.

The experimental design consisted of blocks, randomly distributed, with four replications. Treatments consisted of different application times of the total $\mathrm{N}$ rate splitting, recommended for corn (Comissão de Fertilidade do Solo, 1995), involving $\mathrm{N}$ applications in pre-sowing, at sowing and as side dressing. At Itaara, the rate of 150 $\mathrm{kg} \mathrm{ha}^{-1}$ of $\mathrm{N}$ was split as follows: a) without $\mathrm{N}$ application; b) 0; 30 and $120 \mathrm{~kg} \mathrm{ha}^{-1}$ of $\mathrm{N}$; c) 40; 30 and $80 \mathrm{~kg} \mathrm{ha}^{-1}$ of $\mathrm{N}$; d) 80; 30 and $40 \mathrm{~kg} \mathrm{ha}^{-1}$ of $\mathrm{N}$; e) $120 ; 30$ and $0 \mathrm{~kg} \mathrm{ha}^{-1}$ of $\mathrm{N}$, applied pre-sowing (eight days before), at sowing and side dressing, respectively. At Santo Ângelo, the rate of $99 \mathrm{~kg} \mathrm{ha}^{-1}$ of $\mathrm{N}$ was split as follows: a) without $\mathrm{N}$ application; b) 99; 0 and $0 \mathrm{~kg} \mathrm{ha}^{-1}$ of $\mathrm{N}$; c) 0; 99 and 0 $\mathrm{kg} \mathrm{ha}^{-1}$ of $\mathrm{N}$; d) 0; 0 and $99 \mathrm{~kg} \mathrm{ha}^{-1}$ of $\mathrm{N}$; e) 0; 33 and 66 $\mathrm{kg} \mathrm{ha}^{-1}$ of $\mathrm{N} ;$ f) $0 ; 66$ and $33 \mathrm{~kg} \mathrm{ha}^{-1}$ of $\mathrm{N} ; \mathrm{g}$ ) 33; 0 and 66 $\mathrm{kg} \mathrm{ha}^{-1}$ of $\mathrm{N}$; h) 33; 33 and $33 \mathrm{~kg} \mathrm{ha}^{-1}$ of $\mathrm{N}$; i) 33; 66 and $0 \mathrm{~kg} \mathrm{ha}^{-1}$ of $\mathrm{N}$; j) 66 ; 0 and $33 \mathrm{~kg} \mathrm{ha}^{-1}$ of $\mathrm{N}$; k) 66; 33 and $0 \mathrm{~kg} \mathrm{ha}^{-1}$ of $\mathrm{N}$, applied pre-sowing (35 days before), at sowing and side dressing, respectively. At Júlio de Castilhos, the rate of $120 \mathrm{~kg} \mathrm{ha}^{-1}$ of $\mathrm{N}$ was split follows: a) without $\mathrm{N}$ application; b) 96; 24 and $0 \mathrm{~kg} \mathrm{ha}^{-1}$ of $\mathrm{N}$; ) 45; 24 and $51 \mathrm{~kg} \mathrm{ha}^{-1}$ of $\mathrm{N}$; d) 0; 24 and $96 \mathrm{~kg} \mathrm{ha}^{-1}$ of $\mathrm{N}$, applied pre-sowing (12 days before), at sowing and side dressing, respectively. At Tupanciretã, the rate of $90 \mathrm{~kg}$ $\mathrm{ha}^{-1}$ of $\mathrm{N}$ was split the following way: a) application of only $30 \mathrm{~kg} \mathrm{ha}^{-1}$ of $\mathrm{N}$ at sowing; b) $0 ; 30$ and $60 \mathrm{~kg} \mathrm{ha}^{-1}$ of $\mathrm{N}$; c) $30 ; 30$ and $30 \mathrm{~kg} \mathrm{ha}^{-1}$ of $\mathrm{N}$; d) $60 ; 30$ and $0 \mathrm{~kg} \mathrm{ha}^{-1}$ of $\mathrm{N}$, applied pre-sowing (07 days before), at sowing and side dressing, respectively. Side dress $\mathrm{N}$ application was performed applying urea $0.20 \mathrm{~m}$ next to the corn line without mechanical incorporation, but in a wet soil condition. At Júlio de Castilhos, Tupanciretã and Itaara corn was sown during the first fortnight of October, while

Table 1 - Soil characteristics at the locations where the experiments were carried out(1).

\begin{tabular}{|c|c|c|c|c|c|}
\hline Location & Clay & $\mathrm{pH}-\mathrm{H}_{2} \mathrm{O}$ & Phosphorus $^{(2)}$ & Potassium $^{(2)}$ & Organic matter \\
\hline & $\mathrm{g} \mathrm{kg}^{-1}$ & & - --1 m & 3 - & ----- g dm-3 -.-- \\
\hline Itaara & 420 & 5.4 & 15.8 (high) & 148 (high) & 32 \\
\hline Santo Ângelo & 700 & 5.8 & 8.7 (high) & 124 (high) & 34 \\
\hline Júlio de Castilhos & 410 & 5.6 & 3.2 (low) & 118 (sufficient) & 19 \\
\hline Tupanciretã & 700 & 5.7 & 14.0 (high) & 144 (high) & 33 \\
\hline
\end{tabular}

(1) Soil analysis data were obtained at the routine laboratory of UFSM, according to Tedesco et al. (1995).

(2)High, low and sufficient concentrations are based on recommendations of the bulletin for the States of Rio Grande do Sul and Santa Catarina (Comissão de Fertilidade do Solo, 1995). 
in Santo Ângelo during the second fortnight of September. At all locations the hybrid AG 9014 was used.

At Itaara and Santo Ângelo $100 \mathrm{~kg} \mathrm{P}_{2} \mathrm{O}_{5}$ ha-1 $^{-1}$ were applied as triple super phosphate and $100 \mathrm{~kg}^{\circ} \mathrm{K}_{2} \mathrm{O} \mathrm{ha}{ }^{-1}$ as potassium chloride, both broadcasted before corn sowing. At those two locations, $\mathrm{N}$ at sowing was applied in furrows, $5 \mathrm{~cm}$ aside the mechanical sowing furrow, using urea, while at Júlio de Castilhos and Tupanciretã, $300 \mathrm{~kg} \mathrm{ha}^{-1}$ of a fertilizer formulated as 8-18-28 and 1018-20 (N- $\left.\mathrm{P}_{2} \mathrm{O}_{5}-\mathrm{K}_{2} \mathrm{O}\right)$ were applied, respectively, using a no-tillage planter.

Sampling areas to evaluate corn grain yield were $20 \mathrm{~m}^{2}$ at Itaara and Santo Ângelo, $100 \mathrm{~m}^{2}$ at Julio de Castilhos and $50,4 \mathrm{~m}^{2}$ at Tupanciretã. Additionally, at Itaara, plant height and corn ear insertion of 10 plants chosen at random per sampling area, were measured. At Itaara, soil mineral $\mathrm{N}\left(\mathrm{NH}_{4}^{+}+\mathrm{NO}_{3}^{-}\right)$was measured for the layers $0-5,5-10,10-20$ and $20-40 \mathrm{~cm}$, the samples having been collected immediately before corn sowing, before $\mathrm{N}$ application as sidedressing and immediately after corn harvest. At Santo Ângelo, soil mineral $\mathrm{N}$ was measured for the layers $0-5,5-10$ and $10-20 \mathrm{~cm}$, the samples having been collected at sowing and 95 days after corn sowing, which corresponded to the initial stage of grain filling. Also at Santo Ângelo, the quantity and the accumulated total $\mathrm{N}$ in the dry matter of corn shoots were evaluated in 5 plants for each sampling area at the flowering stage. Analytical procedure followed the method described by Tedesco et al. (1995) and the mineral $\mathrm{N}$ extracted by a $\mathrm{KCl} 1.0 \mathrm{M}$ solution.

\section{RESULTS AND DISCUSSION}

Quantities of soil mineral N, measured immediately before corn sowing at Itaara, presented increasing values in response to the application of larger amounts of pre-sowing $\mathrm{N}$, especially in layers closer to the soil surface (Table 2). However, for mineral $\mathrm{N}$ evaluation performed immediately before $\mathrm{N}$ application as side dressing, there was almost no difference of $\mathrm{N}$ in depth between treatments.

Mineral $\mathrm{N}$ at corn harvest indicated that for the traditional management system, corresponding to 30 and $120 \mathrm{~kg} \mathrm{ha}^{-1}$ of $\mathrm{N}$ applied at sowing and side dressing, respectively, the largest proportions of mineral $\mathrm{N}$ were found in the soil, in the 0 to 5 and 5 to $10 \mathrm{~cm}$ layers. This means that the $\mathrm{N}$ availability in the soil, at the end of the corn cycle was higher when $120 \mathrm{~kg} \mathrm{ha}^{-1}$ of $\mathrm{N}$ were applied as side dressing. The greater $\mathrm{N}$ availability did not reflect an increase of grain yield (Table 3), although there was a productivity limitation due to water deficiency periods starting at corn flowering.

Table 2 - Mineral nitrogen concentration in the soil before and after corn cultivated in succession to black oat at Itaara, considering the times of $\mathrm{N}$ application, 1996/97.

\begin{tabular}{|c|c|c|c|c|c|}
\hline \multirow[t]{2}{*}{ Depth $^{1}$} & \multicolumn{5}{|c|}{$\mathrm{N}$ ap plication times for corn $\mathrm{kg} \mathrm{ha}^{-1(2)}$} \\
\hline & $00-00-00^{(2)}$ & $00-30-120$ & $40-30-80$ & $80-30-40$ & $120-30-00$ \\
\hline \multirow[t]{2}{*}{$\mathrm{cm}$} & \multicolumn{5}{|c|}{ mg N kg${ }^{1}$ of soil - } \\
\hline & \multicolumn{5}{|c|}{ Immediately before corn sowing } \\
\hline $0-5$ & $5.23 \mathrm{aC}^{(3)}$ & $5.23 \mathrm{aC}$ & $19.47 \mathrm{aB}$ & $23.17 \mathrm{aB}$ & $45.57 \mathrm{aA}$ \\
\hline $5-10$ & $7.13 \mathrm{aC}$ & $7.13 \mathrm{aC}$ & $11.63 \mathrm{bC}$ & $19.03 \mathrm{aB}$ & $45.46 \mathrm{aA}$ \\
\hline $10-20$ & $4.06 \mathrm{abC}$ & $4.06 \mathrm{abC}$ & $8.43 \mathrm{bB}$ & $11.87 \mathrm{bB}$ & $24.10 \mathrm{bA}$ \\
\hline $20-40$ & $0.93 \mathrm{bB}$ & $0.93 \mathrm{bB}$ & $2.86 \mathrm{cB}$ & $6.30 \mathrm{bA}$ & $7.53 \mathrm{cA}$ \\
\hline \multirow[t]{2}{*}{ Average $^{(4)}$} & 3.02 & 3.02 & 7.42 & 14.54 & 21.17 \\
\hline & \multicolumn{5}{|c|}{ Imme diately before $\mathrm{N}$ application as sidedressing } \\
\hline $0-5$ & $2.07 \mathrm{aA}$ & $1.74 \mathrm{aA}$ & $2.58 \mathrm{bA}$ & $1.91 \mathrm{aA}$ & $2.09 \mathrm{bA}$ \\
\hline $5-10$ & $1.29 \mathrm{abB}$ & $1.42 \mathrm{aAB}$ & $3.06 \mathrm{bA}$ & $2.12 \mathrm{aAB}$ & $3.06 \mathrm{abA}$ \\
\hline $10-20$ & $0.90 \mathrm{bB}$ & $1.49 \mathrm{aB}$ & $1.62 \mathrm{bB}$ & $2.13 \mathrm{aB}$ & $4.12 \mathrm{aA}$ \\
\hline $20-40$ & $0.50 \mathrm{bB}$ & $1.16 \mathrm{aB}$ & $5.82 \mathrm{aA}$ & $3.84 \mathrm{aAB}$ & $3.70 \mathrm{abAB}$ \\
\hline \multirow[t]{2}{*}{ Average } & 0.89 & 1.34 & 4.02 & 2.95 & 3.52 \\
\hline & \multicolumn{5}{|c|}{ Immediately after corn harvest } \\
\hline $0-5$ & $2.62 \mathrm{aB}$ & $15.20 \mathrm{aA}$ & $7.03 \mathrm{aB}$ & $4.87 \mathrm{aB}$ & $4.07 \mathrm{aB}$ \\
\hline $5-10$ & $1.09 \mathrm{bB}$ & $8.23 \mathrm{bA}$ & $2.90 \mathrm{bB}$ & $3.74 \mathrm{abB}$ & $3.83 \mathrm{aB}$ \\
\hline $10-20$ & $0.71 \mathrm{bB}$ & $4.06 \mathrm{bcA}$ & $2.58 \mathrm{bAB}$ & $3.23 \mathrm{bA}$ & $3.29 \mathrm{abA}$ \\
\hline $20-40$ & $0.36 \mathrm{bB}$ & $1.29 \mathrm{cA}$ & $1.95 \mathrm{bA}$ & $1.97 \mathrm{cA}$ & $1.67 \mathrm{bA}$ \\
\hline Average & 0.82 & 4.59 & 2.83 & 2.87 & 3.48 \\
\hline
\end{tabular}

(1) Soil sampling depth.

(2) $00-00-00=$ corresponds to rates of $\mathrm{N}$ application $\left(\mathrm{kg} \mathrm{ha}^{-1}\right)$, as pre-sowing and side dressing, respectively.

${ }^{(3)}$ Averages with the same capital letter on the line and regular letter in the column do not differ by the Duncan test at $5 \%$.

(4) Weighted average $=[(0-5) \times 5+(5-10) \times 5+(10-20) \times 10+(20-40) \times 20] / 40$ 
At Itaara, $\mathrm{N}$ application led to an average increment of $31 \%$ in corn yield, equivalent to $6.42 \mathrm{Mg} \mathrm{ha}^{-1}$, a satisfactory productivity for corn cultivated without irrigation. There was, however, no influence of the $\mathrm{N}$ application time. Only plant height increased $10 \mathrm{~cm}$ in the cases where all fertilization recommended for side dressing was applied pre-sowing. Simultaneous to the experiment of Itaara, an experiment at Santa Maria, which, in the first year, received $\mathrm{N}$ at pre-sowing of part or all $\mathrm{N}$ which would be applied as side dressing, had higher corn grain productivity (Basso \& Ceretta, 2000).

Average grain productivities at Júlio de Castilhos and Tupanciretã (Table 4) were low, one explanation for this being the final plant population, which was of about $37,000 \mathrm{ha}^{-1}$, due to initial difficulties in crop establishment, reflecting the reality of most corn fields. Besides, during the 1998/99 season, periods of water deficiy prevailed, which limited corn productivity. As a consequence, at Júlio de Castilhos and Tupanciretã, there was no response to $\mathrm{N}$ application as well as to the different splittings of this fertilization, this being a typical answer of the corn crop under water deficit especially when this happens in critical periods of the crop (Bolton, 1971; Morgado, 1986), as it was the case in these locations.

During the 1997/98 season, at Santo Ângelo, the "El Niño" phenomenon occurred, characterized by more frequent rain than usual (Figure 1). This became evident by the $229 \mathrm{~mm}$ of rain between pre-sowing $\mathrm{N}$ application and sowing, being the reason for the sowing delay which occurred only 35 days after $\mathrm{N}$ application. Considering the period between pre-sowing $\mathrm{N}$ application and side dressing, the total rainfall was $565 \mathrm{~mm}$, in 80 days. Approximately during a month after side dress fertilization, rainfall was much superior as compared to the average.

High mobility of nitrate in the soil, associated to the "El Niño" (high precipitation) may explain the low

Table 3 - Plant height, ear insertion height, and grain yield for corn cultivated in succession to black oat, with different forms of $\mathrm{N}$ fertilization, at Itaara. 1996/97.

\begin{tabular}{|c|c|c|c|}
\hline $\begin{array}{l}\mathrm{N} \\
\text { application }\end{array}$ & $\begin{array}{c}\text { Plant } \\
\text { height }\end{array}$ & $\begin{array}{c}\text { Ear insertion } \\
\text { height }\end{array}$ & Grain yield \\
\hline $\mathrm{kg} \mathrm{ha}^{-1}$ & \multicolumn{2}{|c|}{------------- cm ------------- } & $\mathrm{mg} \mathrm{ha}^{-1}$ \\
\hline \multicolumn{4}{|l|}{ PS-SO-SD ${ }^{(1)}$} \\
\hline $00-00-00$ & $197 c^{(2)}$ & $116 \mathrm{~b}$ & $4.89 \mathrm{~b}$ \\
\hline $00-30-120$ & $200 \mathrm{bc}$ & 124 a & 6.48 a \\
\hline $40-30-80$ & $207 a b$ & $125 a$ & $6.21 \mathrm{a}$ \\
\hline $80-30-40$ & $209 a b$ & $130 \mathrm{a}$ & $6.43 \mathrm{a}$ \\
\hline $120-30-00$ & $210 a$ & $126 \mathrm{a}$ & $6.48 \mathrm{a}$ \\
\hline CV (\%) & 2.8 & 3.0 & 8.9 \\
\hline
\end{tabular}

${ }^{(1)}$ Corresponds to the times of nitrogen application splitting: $\mathrm{PS}=$ pre-sowing (8 days before sowing), $\mathrm{SO}=$ sowing, and $\mathrm{SD}=$ side dressing (stage V6).

${ }^{(2)}$ Averages followed by the same letter do not differ by the Duncan test at $5 \%$. proportions of mineral soil $\mathrm{N}$ when plants were at the initial stage of grain filling (Figure 2) and this limited grain yield (Table 5). It was observed in the field that for those systems where $\mathrm{N}$ had been applied as side dressing, plants were darker green, as compared to those that received at pre-sowing most or all nitrogen, resulting in yellowish green, commonly associated to $\mathrm{N}$ deficiency. The lowest $\mathrm{N}$ concentrations in plant tissues for treatments 99-00-00 and 66-33-00 confirm this evidence. The occurrence of long periods of overcast weather and rainfall much above average, decreased light intensity during plant development and favored an intense attack of the leaf smut (Puccinia sp.). The result was reflected in the low dry matter production of corn, which reached a maximum of $3.37 \mathrm{Mg} \mathrm{ha}^{-1}$.

Similar results were also obtained by authors of an experiment carried out simultaneously at Santa Maria, for the second year, since during the first year there was no "El Niño" effect (Basso \& Ceretta, 2000).

Favorable environment for nitrate leaching had an impact on grain productivity. In most cases, side dressing $\mathrm{N}$ application for corn was profitable, leading to a grain productivity increase in relation to pre-sowing $\mathrm{N}$ application. A good example is shown by the treatments of $33 \mathrm{~kg} \mathrm{ha}^{-1}$ of $\mathrm{N}$ applied at sowing and $66 \mathrm{~kg} \mathrm{ha}^{-1}$ of $\mathrm{N}$ as side dressing, which gave an increment of $13 \%$ in grain yield $\left(660 \mathrm{~kg} \mathrm{ha}^{-1}\right)$, when compared to the treatment of pre-sowing $66 \mathrm{~kg} \mathrm{ha}^{-1}$ of $\mathrm{N}$, instead of side dressing.

The $\mathrm{N}$ applied to corn at sowing can influence the response to pre-sowing $\mathrm{N}$ application, because the total concentrations of $\mathrm{N}$ in the soil after the growth of

Table 4 - Grain yield of corn cultivated in succession to black oats with different $\mathrm{N}$ fertilizer application splittings, at Júlio de Castilhos and Tupanciretã. 1998/99.

\begin{tabular}{lc}
\hline $\mathrm{N}$ application & Grain yield \\
\hline $\mathrm{kg} \mathrm{ha}^{-1}$ & ---------- $\mathrm{Mg} \mathrm{ha}^{-1}$-----------
\end{tabular}

\begin{tabular}{ll} 
PS-SO-SD(1) & \\
$00-00-00$ & $4.62 \mathrm{a}^{(2)}$ \\
$90-30-00$ & $4.61 \mathrm{a}$ \\
$45-30-45$ & $4.57 \mathrm{a}$ \\
$00-30-90$ & $4.52 \mathrm{a}$ \\
\hline CV $(\%)$ & 7.4 \\
\hline \multicolumn{3}{c}{} \\
\hline $00-30-00$ & $3.81 \mathrm{a}^{(3)}$ \\
$00-30-60$ & $4.36 \mathrm{a}$ \\
\hline $30-30-30$ & $4.34 \mathrm{a}$ \\
\hline $60-30-00$ & $4.41 \mathrm{a}$ \\
\hline CV $(\%)$ & 25.79 \\
\hline
\end{tabular}

${ }^{(1)}$ Corresponds to the times of nitrogen application splitting: $\mathrm{PS}=$ pre-sowing (12 days before sowing), $\mathrm{SO}=$ sowing, and $\mathrm{SD}=$ side dressing (stage V6).

(2),(3)Averages followed by the same letter do not differ by the Duncan test at $5 \%$. 
Table 5 - Dry matter production, nitrogen concentration in shoots of corn at flowering and grain yield, cultivated in succession to black oat, with different nitrogen fertilization splittings at Santo Ângelo, 1997/98.

\begin{tabular}{lccc}
\hline N application & $\begin{array}{c}\text { Dry matter } \\
\text { production }\end{array}$ & $\begin{array}{c}\text { Tissue N } \\
\text { concentration }\end{array}$ & Grain yield \\
\hline $\mathrm{kg} \mathrm{ha}^{-1}$ & $\mathrm{Mg} \mathrm{ha}^{-1}$ & $\mathrm{~g} \mathrm{~kg}^{-1} \mathrm{DM}$ & $\mathrm{Mg} \mathrm{ha}^{-1}$ \\
${\mathrm{PS}-S O-S D^{(1)}}$ & & & \\
$00-00-00$ & $2.35 \mathrm{~ns}$ & $17.1 \mathrm{c}^{(2)}$ & $4.80 \mathrm{e}^{(2)}$ \\
$99-00-00$ & 2.92 & $18.8 \mathrm{~b}$ & $5.23 \mathrm{cde}$ \\
$00-99-00$ & 2.72 & $21.7 \mathrm{a}$ & $5.23 \mathrm{cde}$ \\
$00-00-99$ & 3.37 & $22.4 \mathrm{a}$ & $5.44 \mathrm{bcde}$ \\
$00-33-66$ & 3.37 & $22.8 \mathrm{a}$ & $5.73 \mathrm{abcd}$ \\
$66-33-00$ & 3.01 & $20.5 \mathrm{~b}$ & $5.07 \mathrm{de}$ \\
$33-33-33$ & - & - & $5.70 \mathrm{abcd}$ \\
$33-66-00$ & - & - & $6.16 \mathrm{a}$ \\
$00-66-33$ & - & - & $5.62 \mathrm{abcd}$ \\
$33-00-66$ & - & - & $5.80 \mathrm{abc}$ \\
$66-00-33$ & - & - & $5.97 \mathrm{a}$ \\
\hline CV (\%) & 21.1 & 4.6 & 7.9 \\
\hline
\end{tabular}

(1)Nitrogen application times: $P S=$ pre-sowing (35 days before sowing), $\mathrm{SO}=$ sowing, and $\mathrm{SD}=$ side dressing (stage $\mathrm{V} 6$ ). $\mathrm{DM}=$ dry matter.

(2)Averages followed by the same letter do not differ by the Duncan test at $5 \%$.

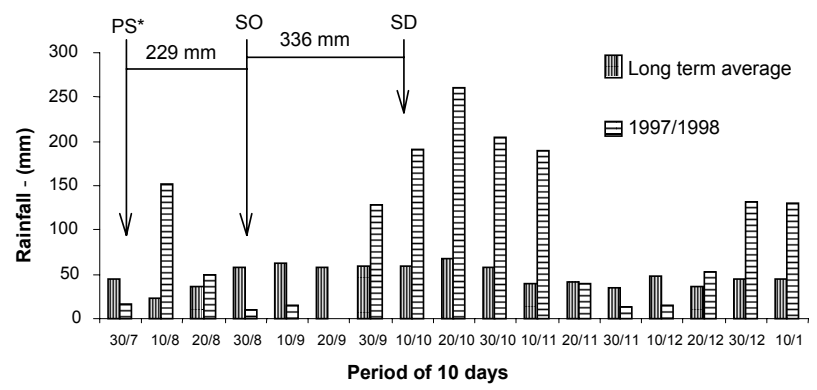

Figure 1 - Ten day rainfall, of the experimental period at Santo Ângelo, 1997/98. *PS=pre-sowing (17/07), SO=sowing $(21 / 08)$ and $\mathrm{SD}=$ sidedressing $(05 / 10)$.

forage grass or legumes preceding corn, may vary little (Gonçalves et al., 2000) and alter corn productivity (Aita et al., 1994). This happens because $\mathrm{N}$ immobilization by microorganisms is significant in the no-tillage system as compared to other soil management practices (Fernandes et al., 1998). Wiethölter (1996) highlighted that, if in a certain way one can expect an increase in $\mathrm{N}$ availability for notillage systems, on the other hand the organic matter content increase also indicates an increase in the quantity of immobilized $\mathrm{N}$ in the soil. For this reason Bayer (1993) recommended higher $\mathrm{N}$ rates for corn under the no-tillage system. Therefore, pre-sowing $\mathrm{N}$ application for corn should probably not be considered as the best option under no-tillage, according to Sá (1996), but one should consider the possibility of the application of part, but not all $\mathrm{N}$, as side dressing, as



(a)

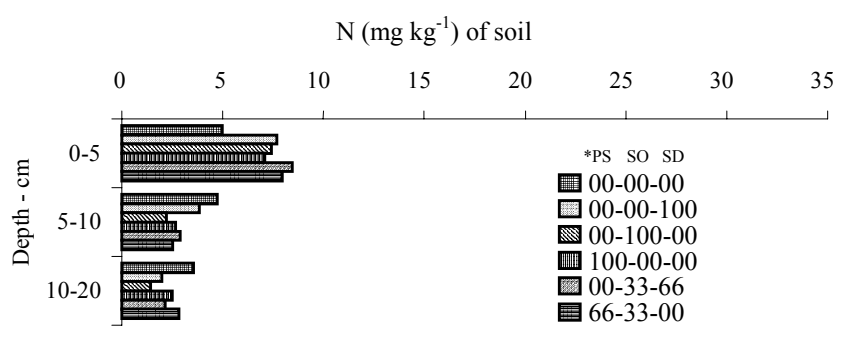

(b)

Figure 2 - Soil mineral nitrogen concentration $\left(\mathrm{NO}_{3}^{-}+\mathrm{NH}_{4}^{+}\right)$evaluated immediately before sowing (a) and 95 days after corn sowing (beginning of grain filling, (b), in Santo Ângelo. "kg of $\mathrm{N} \mathrm{ha}^{-1}$ applied: $\mathrm{PS}=$ pre-sowing, $\mathrm{SO}=$ sowing and $\mathrm{SD}=$ side dressing.

highlighted by Ceretta (1997), especially when looking for high productivity.

\section{CONCLUSIONS}

Pre-sowing application for corn of part or all nitrogen that would be applied as side dressing did not improve grain productivity in relation to the application at sowing or by side dressing. Rainfall above average can, however, cause a decrease in grain productivity for pre-sowing nitrogen application.

\section{ACKNOWLEDGMENTS}

To the owners of the Céu Azul farm (Júlio de Castilhos), Bruno Eisele (Santo Ângelo), Celso Ferigolo (Itaara) and Pedro Luiz Herter (Tupanciretã); the students Alaerto Luiz Marcolan (BIC-FAPERGS), Tatiana Taschetto Fiorin (BIC-FAPERGS) and Aldo Tisott (BICCNPq), and Vagner Soldera. To CNPq and FAPERGS for the financial support.

\section{REFERENCES}

AITA, C.; CERETTA, C.A.; THOMAS, A.L.; PAVINATO, A.; BAYER, C. Espécies de inverno como fonte de nitrogênio para o milho no sistema de cultivo mínimo e feijão em plantio direto. Revista Brasileira de Ciência do Solo, v.18, p.101-108, 1994.

BASSO, C.J.; CERETTA, C.A. Manejo do nitrogênio no milho em sucessão a plantas de cobertura de solo, sob plantio direto. Revista Brasileira de Ciência do Solo, v.24, p.905-915, 2000. 
BAYER, C. Manejo da fertilidade do solo na cultura do milho. In: BRESOLIN, M. (Ed.) Contribuições para a cultura do milho para o estado do Rio Grande do Sul. Porto Alegre: Fundação de Ciência e Tecnologia CIENTEC, 1993. p.71-93.

BOLTON, A. Response of maize varieties in Tanzania to different plant population and fertilizer levels. Experimental Agriculture, v.6, p.193-203, 1971.

CERETTA, C.A. Manejo da adubação nitrogenada na sucessão aveia/milho, no sistema plantio direto. In: CURSO DE ATUALIZAÇÃO EM RECOMENDAÇÕES DE ADUBAÇÃO E CALAGEM, ÊNFASE EM PLANTIO DIRETO, 3., Santa Maria, 1997. Anais. Santa Maria, p.112124.

CERETTA, C.A. Adubação nitrogenada no sistema plantio direto: sucessão aveia/milho. In: CONFERÊNCIA ANUAL DO PLANTIO DIRETO, 1., ljuí, 1998. Resumo de palestras. p.49-62.

COMISSÃO DE FERTILIDADE DO SOLO - RS/SC. Recomendação de adubação e calagem para o Estado do Rio Grande do Sul e Santa Catarina. 3.ed. Passo Fundo: SBCS Núcleo Regional Sul; EMBRAPA, CNPT, 1995. 223p.

FANCELLI, A.L.; DOURADO-NETO, D. Cultura do milho: aspectos fisiológicos e manejo da água. Informações Agronômicas, n.73, p.1-4, 1996.

FERNANDES, L.A.; FURTINI NETO, A.E.; VASCONCELLOS, C.A.; GUEDES G.A.A. Preparo do solo e adubação nitrogenada na produtividade de milho em latossolo sob vegetação de cerrado. Revista Brasileira de Ciência do Solo, v.22, p.247-254, 1998.

GONÇALVES, C.N.; CERETTA, C.A.; BASSO, C.J. Sucessões de culturas com plantas de cobertura e milho em plantio direto e sua influência sobre o nitrogênio no solo. Revista Brasileira de Ciência do Solo, v.24, p.153$159,2000$.
MORGADO, L.B. Níveis de adubação para culturas consorciadas. Resposta do milho a nitrogênio em plantios isolados com caupi sob déficit de água no solo. Pesquisa Agropecuária Brasileira, v.21, p.375-382, 1986.

RITCHIE, S.W.; HANWAY, J.J.; BENSON, G.O. How a corns plant develops. Ames: lowa State University of Science and Techonology, Cooperative Extention Service, 1993. 21p. (Special Report, 48).

SÁ. J.C de M. Manejo de nitrogênio na cultura do milho no sistema plantio direto. Passo Fundo: Aldeia Norte, 1996. 24p.

SALET, R.L.; VARGAS, L.K.; ANGHINONI, I.; KOCHHANN, R.A.; DENARDIN, J.E.; CONTE, E. Por que a disponibilidade de nitrogênio é menor no sistema de plantio direto? In: SEMINÁRIO INTERNACIONAL DO SISTEMA DE PLANTIO DIRETO, 2., Passo Fundo, 1997. Anais. Passo Fundo: Aldeia Norte Editora, 1997. p.217-219.

TEDESCO, M.J.; GIANELLO, C.; BISSANI, C.A.; BOHNEN, H.; VOLKWEISS, S.J. Análise de solo, plantas e outros materiais. Porto Alegre: UFRGS, 1995. 174p.

WIETHÖLTER, S. Adubação nitrogenada no sistema plantio direto. Passo Fundo: EMBRAPA, CNPT, 1996. 44p.

YAMADA, T. Adubação nitrogenada no milho: quanto, como e quando aplicar. Informações Agronômicas, n.74, p.1-5, 1996.

Received April 26, 2001 